
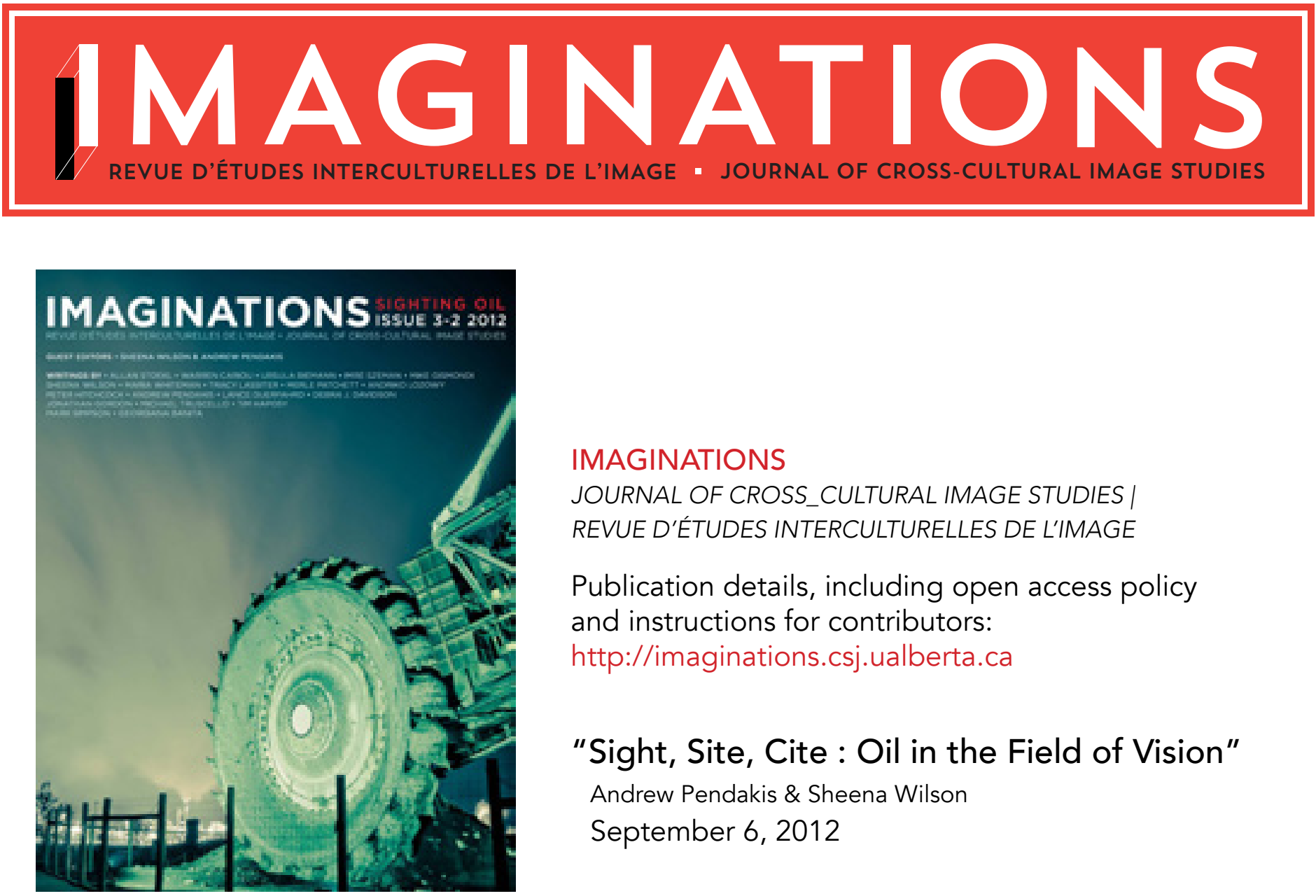

\author{
IMAGINATIONS \\ JOURNAL OF CROSS_CULTURAL IMAGE STUDIES | \\ REVUE D'ÉTUDES INTERCULTURELLES DE L'IMAGE \\ Publication details, including open access policy \\ and instructions for contributors: \\ http://imaginations.csj.ualberta.ca
}

"Sight, Site, Cite : Oil in the Field of Vision"

Andrew Pendakis \& Sheena Wilson

September 6, 2012

To Cite this Article:

Pendakis, Andrew and Sheena Wilson. "Sight, Site, Cite : Oil in the Field of Vision"

Imaginations 3:2 (2012): Web (date accessed) 4-5. DOI: 10.17742/IMAGE.sightoil.3-2.1

To Link to this article:

http://dx.doi.org/10.17742/IMAGE.sightoil.3-2.1

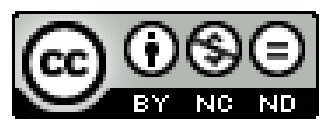

The copyright for each article belongs to the author and has been published in this journal under a Creative Commons Attribution NonCommercial NoDerivatives 3.0 license that allows others to share for non-commercial purposes the work with an acknowledgement of the work's authorship and initial publication in this journal. The content of this article represents the author's original work and any third-party content, either image or text, has been included under the Fair Dealing exception in the Canadian Copyright Act, or the author has provided the required publication permissions. 


\section{SIGHT, SITE, CITE: OIL IN THE FIELD OF VISION}

\section{ANDREW PENDAKIS AND SHEENA WILSON}

The image we have chosen for the cover of this special issue on oil and visuality nicely frames our problematic. To one side, burns oil literalized, oil in the shape of its own productive apparatus, the classical image of the silent, effective refinery. This is a culturally transparent image, one which domiciles oil's complexity, its life as social process, and even its historical contingency, in the simple immediacy of a functional industrial procedure. Oil does nothing more or less than its societally prescribed duty: there are no spillages or externalities, no leeks in the coherence of its A = A. It may be, however, that this identity is today unravelling and that the refineryhere smoking brightly in the background-already has about it the whiff of an apocalypse, a dying industrial Mordor. Very quickly the gleaming effectiveness of oil's technologies can morph into their opposite: images of excess and failure, a process without a subject, utility pushed to a point without telos or reason, sheer instrumental nihlism. Though we would not want to dismiss the urgency, even the political necessity of this picture, there is a way in which it suffers from the same debilitating iconicity, one which pushes into oblivion the whole ramifying nexus of petroleum. Meanwhile, in the foreground of the image, we are confronted abruptly by an oil extraterrestrial, anonymous, without use or place, beyond sensible scale, a creature, weapon, or tool, perhaps, depending on the light. At once hideous and foreign this is an object freed to a place beyond stable relations, beyond meaning or inherence, pure defamiliarization in all its discomfort and uncertainty.

We do not want to rest content at any moment of this dialectic: not the first stabilized image of functioning production, nor its apocalyptic reversal, nor even this classical figure of aesthetic or epistemological rupture. Instead, looking again at the image, but now from within the spirit of what Ursula Biemann calls visual research, we find a name for the object in the foreground-a 'bucketwheel excavator'-and a context for its display, positioned across from the Syncrude plant on Highway 63 north of Fort McMurray. What initially disturbed us is now understood as a fragment from the oil industry's reproduction of its own techno-historical legitimacy-it is an affair of history and discourse. The bucketwheel in this photo, paired in physical reality with another relic, a dragline excavator, function both to imbricate oil into Albertan and Canadian history, as well as its future. These two machines are an archive of outdated technology and inefficiency that stand in contrast to contemporary oil discourses that revolve around a focus on scientific innovation. It is not enough to defamilarize oil, to free it to some imagined objectal monstrosity or reticence. Rather, the task of visualizing oil, one which goes beyond phenomenology, beyond even the logic of the gaze itself, is that of hoarding maps and screens and files, layering mediums, and setting into motion myriad arts and sciences of oil's determinate presence. This is a task which is by definition endless, but not precisely infinite, not endlessly deferred; or rather, it is one which restlessly explores and investigates a concrete material knot, drawing conclusions as it goes. It is research construed as profusion, but also, crucially, as intervention. This is a picture, then, that owes equal debts to sociology and art history, to discourse analysis and materialist geography, to political economy and the history of science. It is a picture that is not merely an image, but a si(gh)ting.

Sight, site, cite: sighting oil requires this triple passage through vision, space and discourse. Oil, perhaps, is no more invisible that any other element of our postmodern economies, no more occluded, say, than corn or socks or coffee-or even the image itself, for that matter. In the age of oil it is the image, at this time more than in any other era, that proliferates as a medium of communication. And, the very image-technologies that allow us to conceptualize our relationship to energy and petroleum are a product of oil: the first photograph in 1827 resulting from a combined use of bitumen, metals, solar energy and chemicals in a solvent. The problem of visualization, of the proliferation of determinate, useful maps of our economic lives, is not specific to oil, but one politically structural to a system that is at once spectacularly consumerist and fully globalized on the level of production. However, it could be argued that oil is a uniquely occluded substance: not only does its exchange value engender an enormous corporate project of hiding, an explicit machinery of deception and spin, its pervasiveness, its presence everywhere, perhaps singularly christens its position as "hidden in plain sight" (Szeman \& Whiteman). At the same time, 
there is no alternative to oil, no substance available to the system by which its functions can be replaced or exchanged without massive structural disorder; it is this indispensability, the way oil comes to appear more and more like our time's secret substantia that necessitates the diverse situating procedures employed by the various contributors to this collection. Their research makes blatant the visual rhetorical strategies of individuals and groups invested in either maintaining or disrupting hegemonic structures. Taken as a whole the articles in this issue lead us to question how diverse visual petro-narratives function collectively to construct a public understanding, whether factual or fantastical, about the role of oil and energy within our historical moment. Oil in the field of vision: the balance of all that stands to be squandered or saved remains to be seen.

\section{Works Cited}

Szeman, Imre and Maria Whiteman. "Oil Imag(e)ries: Critical Realism and the Oil Sands". Sighting Oil. Spec. Issue of. Imaginations: Journal of Cross-Cultural Image Studies/ Revue d'Études Interculturelles de l'Image 3.2. (Fall 2012). pp. 46-67.

Sheena Wilson est professeure adjointe au Campus SaintJean de Université de l'Alberta. Elle est titulaire d'un doctorat en littérature comparée avec une concentration en études cinématographiques et médiatiques. Elle s'intéresse au rapport entre le mot écrit et l'image comme référents discursifs dans leurs contextes socio-politiques. Ses recherches mènent de manière interdisciplinaire à l'étude des abus humains/civils tels que présentés dans la littérature, les films et les médias. Récemment, sa passion pour les droits humains et pour les questions concernant la femme a suscité son désir d'examiner le rapport entre la marginalisation lié au sexe et les autres types de marginalisation dans le contexte de la culture pétrolière globale. Dr. Wilson est co-directrice de Petrocultures Research Group (petrocultures.com). En 2012 elle a également co-animé (avec Imre Szeman) la conférence internationale Petrocultures: Oil, Energy, Culture. Site web: sheenawilson.ca
Sheena Wilson is Assistant Professor at Campus Saint-Jean, University of Alberta. She holds a $\mathrm{PhD}$ in Comparative Literature with a specialization in Film and Media studies. She is interested in the relationship between the written word and the image as discursive referents in socio-political contexts. Her research involves an interdisciplinary approach to the study of human/civil rights abuses as they are represented in literature, film, and media. More recently, her interest in human rights and women's issues have crossed over into an analysis of the relationship between gendered and other forms of marginalization within context of global oil cultures. Dr Wilson is the co-director of the Petrocultures Research Group (petrocultures.com) and in the fall of 2012 she co-hosted with Imre Szeman, an international conference titled Petrocultures: Energy, Culture. Homepage: sheenawilson.ca

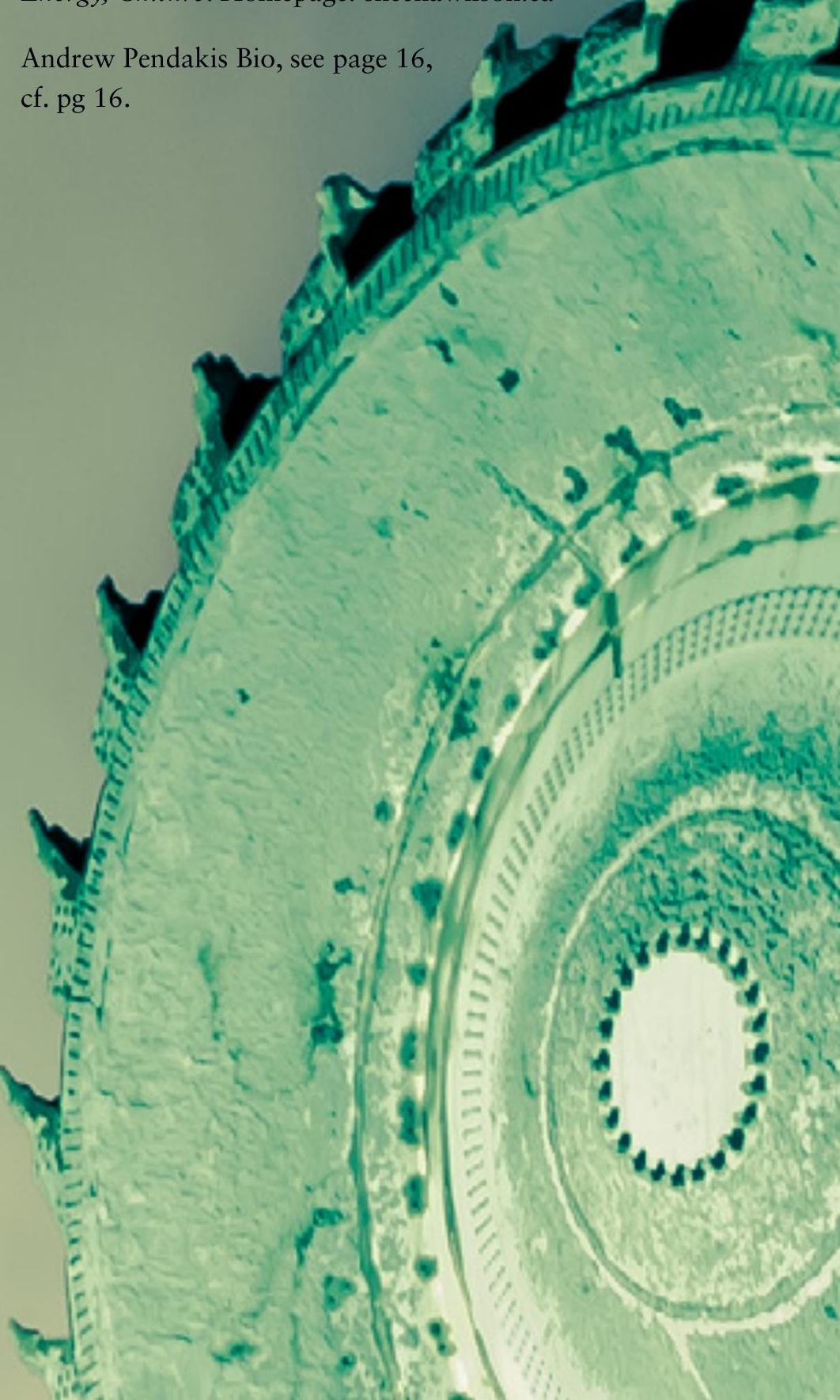

